\title{
Prostasomes: extracellular vesicles from the prostate
}

\author{
Marian Aalberts ${ }^{1}$, Tom A E Stout $^{2}$ and Willem Stoorvogel ${ }^{1}$ \\ Departments of ${ }^{1}$ Biochemistry and Cell Biology and ${ }^{2}$ Equine Sciences, Faculty of Veterinary Medicine, \\ Utrecht University, PO Box 80.176, NL-3508 TD Utrecht, The Netherlands
}

Correspondence should be addressed to W Stoorvogel; Email: W.Stoorvogel@uu.nl

\begin{abstract}
The term 'prostasomes' is generally used to classify the extracellular vesicles (EVs) released into prostatic fluid by prostate epithelial cells. However, other epithelia within the male reproductive tract also release EVs that mix with 'true' prostasomes during semen emission or ejaculation. Prostasomes have been proposed to regulate the timing of sperm cell capacitation and induction of the acrosome reaction, as well as to stimulate sperm motility where all three are prerequisite processes for spermatozoa to attain fertilising capacity.

Other proposed functions of prostasomes include interfering with the destruction of spermatozoa by immune cells within the female reproductive tract. On the other hand, it is unclear whether the distinct presumed functions are performed collectively by a single type of prostasome or by separate distinct sub-populations of EVs. Moreover, the exact molecular mechanisms through which prostasomes exert their functions have not been fully resolved. Besides their physiological functions, prostasomes produced by prostate tumour cells have been suggested to support prostate cancer spread development, and prostasomes in peripheral blood plasma may prove to be valuable biomarkers for prostate cancer.

Reproduction (2014) 147 R1-R14
\end{abstract}

\section{Introduction}

All mammalian cell types examined to date have been shown to release extracellular vesicles (EVs) in vitro, and EVs have been detected in all body fluids. In recent years, it has also become clear that EVs can be important means of intercellular communication, supplementing the more conventional signalling mechanisms provided through direct cell-to-cell contact or by freely soluble signalling molecules (Raposo \& Stoorvogel 2013). The idea that EVs from healthy cells could serve important biological functions was initially treated with scepticism by many scientists, based on the long-standing awareness that in addition to apocrine secretion by some specialised cell types, such as fat globules secreted by mammary epithelial cells, EVs are also abundantly released by apoptotic and necrotic cells. This scepticism ceased, however, in response to the numerous recent publications on molecular mechanistic aspects of EV formation and selective incorporation of 'cargo' including (glyco)proteins, lipids and RNA, and with the discovery of molecular pathways that can explain some of the demonstrated functions of EVs in body fluids. EVs include so-called exosomes, which are most often referred to as intraluminal vesicles of multivesicular bodies (MVBs) and that are released when MVBs fuse with the plasma membrane. Other types of EVs may be produced through shedding from the plasma membrane, and we here refer to these as microvesicles. In the literature, it is often unclear whether reported EVs are exosomes or microvesicles, and, therefore, it is often more adequate to use the more comprehensive term 'EVs'. Cell-derived EVs have been demonstrated to regulate a variety of physiological processes, including adaptive immune responses, as well as to impact on pathological processes, like tumour development. Moreover, preexisting EV pathways are thought to be exploited for the secretion of certain enveloped viruses, prions and amyloid peptides (Raposo \& Stoorvogel 2013).

EVs in seminal plasma and prostatic fluid were first reported in the 1970s (Ronquist \& Hedstrom 1977, Ronquist et al. 1978a, 1978b) and have been the topic of excellent recent reviews (Ronquist 2012, Sullivan \& Saez 2013). EVs from the prostate epithelium, now known as prostasomes, correspond in size to vesicles found inside the so-called 'storage vesicles' within prostate epithelial cells (Brody et al. 1983, Ronquist \& Brody 1985). That storage vesicles are the source of prostasomes was suggested by electron microscopic images from both benign and malignant prostate epithelial cells (Sahlen etal. 2002). Because these storage vesicles resemble MVBs found in other cells types, at least one population of prostasomes may be considered to be exosomes. Consistent with an exosomal nature, prostasomes from the prostate cancer cell line PC-3 have been shown to express proteins that are generally enriched on MVBs, such as MAL, caveolin-1, Tsg101 and Hrs 
(Llorente et al. 2004, 2007). It should be noted, however, that it has never been directly demonstrated that storage vesicles are the exclusive or even the primary source of EVs in seminal plasma. Thus, populations of EVs in semen may originate from the plasma membrane of prostate epithelial cells or even from other sources within the male genital tract, including other accessory sex glands. To appreciate the potential contributors of EVs to seminal plasma, it is important to first evaluate the male reproductive tract and the potential role of EVs therein. The composition of seminal fluid and the biological roles of its components vary widely between mammalian species (Aumüller \& Seitz 1990). Of note, this may include variation in tissue sources and biological functions of EVs, and conclusions drawn for one species cannot be automatically transferred to other species without experimental confirmation.

\section{EVs in the male reproductive tract}

Haploid spermatids mature into sperm cells within the seminiferous tubules. Sperm cells that leave the testis to enter the epididymis have limited biosynthetic capacity and are dependent on transfer of secreted products from epididymal epithelial cells for further maturation (Cooper 1998). Many of these molecules are transferred by epididymosomes, membrane vesicles that are thought to be shed from the epididymal plasma membrane in an apocrine fashion and can thus be characterised as microvesicles (Cornwall 2009). Epididymosomes have heterogeneous diameters ranging from $\sim 0.1$ to $1 \mu \mathrm{m}$ and are produced throughout the epididymal duct, with their precise protein composition depending on the segment of epididymis in which they originate (Girouard et al. 2011). Epididymosomes transfer specific subsets of epididymal membrane proteins to the sperm cell surface (Frenette et al. 2002; Fig. 1). Among these is the GPIanchored protein P34H. P34H (Legare et al. 1999), and its counterparts in other species, such as P26h in the hamster (Gaudreault et al. 1999), P31m in the monkey (Lamontagne et al. 2001) and P25b in the bull (Frenette \& Sullivan 2001), are proteins that enable sperm cells to properly bind to the zona pellucida of an oocyte. Similarly, the transmembrane protein 'a disintegrin and metalloproteinase $7^{\prime}$ (ADAM7 or GP-83) is also transferred by epididymosomes to sperm cells, where it has been proposed to play a role in sperm-oocyte interaction (Sun et al. 2000, Oh et al. 2009). Besides membrane proteins, epididymosomes may also transfer cytosolic proteins, including aldose reductase and sorbitol dehydrogenase, both of which are enzymes of the polyol pathway; the former reduces glucose to sorbitol, while the latter oxidises sorbitol to fructose. As fructose is a major energy source for spermatozoa, these enzymes may play an important role in sperm cell motility (Frenette et al. 2006). In a recent study, in vitro fusion of isolated epididymosomes with sperm was reported (Schwarz et al. 2013), presumably explaining how epididymal epithelial cell cytosolic and membrane constituents can be integrated into sperm cells. Sperm capture of epididymosomes is apparently quite efficient, or epididymosomes are subsequently recaptured by epididymal epithelial cells, as the contribution of nonsperm associated free epididymosomes to the total population of EVs in the ejaculate appears to be low.

Depending on the species, spermatozoa may be stored for between a few days and several weeks in the cauda epididymis (Cornwall 2009). From the epididymis, sperm cells are transported through the ductus deferens to the ampulla, the dilated terminal segment of the distal ductus deferens that serves as an additional short-term sperm reservoir in many mammals but not in humans (Nistal et al. 1992). Secretions of the ductus deferens include vas deferens protein, a protein that lacks a signal sequence and is therefore thought to be released in association with EVs rather than via a conventional secretory pathway (Manin et al. 1995). The ampulla discharges its contents into the prostatic urethra, the location at which both the vesicular glands (confusingly also called the 'seminal vesicles') and the prostate secrete their contents. Although there are betweenspecies differences, in humans the secretions from the vesicular glands account for $50-80 \%$ of seminal volume and contain prostaglandins, fructose and semenogelin I, one of the components responsible for semen coagulation after ejaculation (Aumüller \& Riva 1992, Duncan \& Thompson 2007). The vesicular glands also secrete

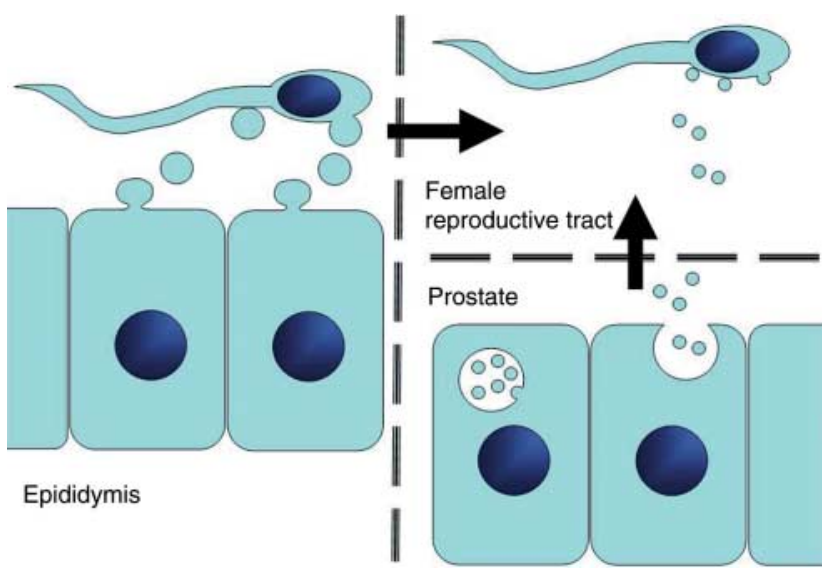

Figure $1 \mathrm{EVs}$ in the reproductive tract. The epididymal epithelium produces EVs that are thought to be shed from the plasma membrane in an apocrine fashion. These vesicles then fuse with the sperm cell plasma membrane enabling the transfer of specific subsets of membrane and cytosolic proteins from epididymal cells to the sperm cells. In the female reproductive tract, sperm cells encounter another subset of EVs: prostasomes. We hypothesise that these vesicles first bind to capacitated sperm cells at a neutral or slightly alkaline $\mathrm{pH}$ and finally fuse with sperm cells only when they encounter a lower $\mathrm{pH}$ possibly in cumulus cell matrix in close proximity to the oocyte. The epididymis, prostate and female reproductive tract are separate compartments as indicated by the dashed lines. 
EVs, which have a protein composition distinct from both epididymosomes and true prostasomes, and unknown function(s) (Sahlen et al. 2010). A prostate is apparent in all mammalian species, and although prostatic secretions may not be absolutely required, they are highly beneficial for fertility (Aumüller \& Seitz 1990). Prostatic fluid accounts for $20-30 \%$ of seminal volume and contains high concentrations of citric acid, zinc and specific enzymes. Two major ones are prostate acid phosphatase (PAP) and prostate-specific antigen (PSA) (Veveris-Lowe et al. 2007, Graddis et al. 2011). The major function of the protease PSA is to liquefy the semen coagulum, although PSA has become better known as a biomarker for prostate cancer (Tosoian \& Loeb 2010). The prostate also produces prostasomes, the primary topic of this review. Finally, the bulbourethral glands, also known as Cowper's glands, discharge into the urethra just before the sciatic arch at the base of the penis. This secretion is the primary component of preejaculatory fluid and accounts for $2-5 \%$ of the total human ejaculate. It contains glycoproteins that lubricate the urethra for spermatozoal passage and neutralises the $\mathrm{pH}$ of any residual urine in the urethra and of the acidic vaginal secretions that the sperm are expected to encounter (Chughtai et al. 2005). We are not aware of any study reporting on the nature of EVs in secretions from the bulbourethral glands.

In short, although the name prostasome is generally applied to all EVs that can be recovered from semen, and the prostate is probably the major contributor of these $\mathrm{EVs}$, it should be taken into account that heterogeneity in the composition or functions of seminal EVs may reflect EVs from distinct sources within the male reproductive tract. Moreover, the presence and functions of the accessory sex glands vary between mammalian species and this may well affect the nature and relative proportions of the contained EVs. For example, dogs do not have bulbourethral or vesicular glands, whereas the vesicular glands in the bull produce significant quantities of membrane vesicles (Agrawal \& Vanha-Perttula 1987). It cannot, therefore, be concluded for all species that the prostate is the major contributor of EVs in the ejaculate.

\section{The molecular composition of prostasomes}

Prostasomes isolated from human semen have been characterised by comprehensive proteomic approaches (Utleg et al. 2003, Poliakov et al. 2009). Interesting components included prostate-specific proteins such as PAP, PSA, type 2 transmembrane serine protease (TMPRSS2), prostate-specific transglutaminase and prostate stem cell antigen (PSCA). These proteins have already been examined as (candidate) markers for prostate cancer (Cho et al. 2010, Bjartell et al. 2011, Graddis et al. 2011, Zhao et al. 2011), among which PSA is the most well known (Tosoian \& Loeb 2010). Given their mutual presence on prostate epithelial cells and prostasomes, these proteins may also serve as markers for 'true' prostasomes. In a recent study, we characterised EVs from seminal fluid obtained from vasectomised men so as to ensure exclusion of contributions from the testes or epididymides (Aalberts et al. 2012). Using this material, two distinct populations of EVs were purified and their further characterisation indicated distinct protein compositions. Both types of $\mathrm{EVs}$ resembled exosomes in terms of buoyant density, size and the presence of CD9, an ubiquitous exosome marker. The prostatic origin of both was indicated by the presence of PSCA. One of the populations had a diameter of $56 \pm 13 \mathrm{~nm}$ and was selectively enriched in GLIPR2/ GAPR-1, a protein that regulates autophagy by interacting with beclin 1 (Shoji-Kawata et al. 2013), possibly indicating an exosomal origin of this population of prostasomes. The second prostasome population constituted larger vesicles $(105 \pm 25 \mathrm{~nm})$ with annexin A1 as an exclusive marker. The most extensively studied proteins in EVs isolated from semen are, however, enzymes that had already been described before this association was revealed. For example, dipeptidyl peptidase IV (DPP4; CD26) was shown to be associated with prostasomes (Bellezza et al. 2005, Carlsson et al. 2006), after having previously been proposed to be transferred to sperm cells by prostasomes (Arienti et al. 1997b). DPP4 is in fact expressed by many cell types and involved in many processes (Boonacker \& Van Noorden 2003), although its role on EVs/sperm cells is unclear. Aminopeptidase $\mathrm{N}$ has also been reported to be transferred to sperm cells by prostasomes (Arienti et al. 1997a, Carlsson et al. 2003, 2006, Siciliano et al. 2008). Like DPP4, it is found on a wide variety of cells types (Mina-Osorio 2008), but in seminal fluid, aminopeptidase $\mathrm{N}$ has been proposed to regulate sperm cell motility through modulation of enkephalin levels (Subiran et al. 2007). In a recent study on EVs isolated from stallion seminal plasma, we found that both DPP4 and aminopeptidase $\mathrm{N}$ are largely confined to vesicles that are much larger than the CD9 carrying prostasomes (Aalberts et al. 2013). It is possible that these large EVs also originate from the prostate, e.g. by shedding from the plasma membrane; however, alternative sources such as the epididymis cannot be excluded (Dubois et al. 2009). Other enzymes that have been reported on prostasomes include 5 ' nucleotidase (Fabiani \& Ronquist 1993, 1995), alkaline phosphatase, alkaline phosphodiesterase I (Fabiani \& Ronquist 1995), neutral endopeptidase (Renneberg et al. 2001), TMPRSS2 (Chen et al. 2010), ecto-diadenosine polyphosphates hydrolase (Minelli et al. 2002), protein kinases A and C (PKA/ PKC), casein kinase $\|$ and membrane-bound ATPase (Babiker et al. 2006).

Prostasomes have a peculiar lipid composition. The main phospholipid in prostasomes is sphingomyelin $(S M)$, whereas mammalian cells contain more abundant quantities of phosphatidylcholine (PC) and 
phosphatidylethanolamine (PE) (Arienti et al. 1998). The prostasomal membrane also has an unusually high cholesterol content. Early studies indicated that the cholesterol:phospholipid ratios in isolates of human and equine prostasomal membranes were 2.0 and 1.7 respectively, whereas the ratio was only 0.67 in the human sperm cell plasma membrane (Carlini et al. 1997, Arienti et al. 1998). The fatty acids in the prostasomal membrane are mostly saturated (stearic and palmitic acid) or monounsaturated (oleic acid) (Arienti et al. 1998). Together with a high concentration of cholesterol, this probably accounts for the very high stability of the prostasomal membrane (Arvidson et al. 1989). In a recent study, we used a lipidomic approach to analyse the lipid composition of two distinct populations of prostasomes that had been purified from the semen of vasectomised men (Brouwers et al. 2013) and confirmed the relatively high enrichments in cholesterol (55\% of total lipid) and SM. In addition, we detected relatively high amounts of monohexosylceramides. Exosome formation is dependent on hydrolysis of SM by neutral sphingomyelinase in the endosomes (Trajkovic et al. 2008). The resulting product, ceramide, may serve as a precursor for the synthesis of hexosyl ceramides or of ceramide 1-phosphate, which we also detected in prostasomes (Brouwers et al. 2013). We speculate that these ceramide derivatives may play a role in the formation of prostasomes in endosomes within prostate epithelial cells. The prostasome glycerophospholipids consisted mainly of monounsaturated species while the sphingosine-based lipids, SM and the monohexosylceramides were characterised by the near absence of unsaturated species (Brouwers et al. 2013).

EVs from many other sources have been reported to contain RNA, including mRNA, miRNA and other small non-coding RNA biotypes with potential regulatory functions (Raposo \& Stoorvogel 2013). Similarly, prostasomes have also been found to contain RNA. For example, in EVs from a prostate tumour cell line, RNA transcripts of the prostate cancer-specific fusion gene TMPRSS2:ERG were detected (Jansen et al. 2009). These transcripts, along with mRNA for GOLPH2, SPINK1 and prostate cancer antigen 3, were also found in EVs isolated from the urine of prostate cancer patients (Laxman et al. 2008, Nilsson et al. 2009, Leyten et al. 2012). In semen, cell-free mRNA and miRNA were found both in association with EVs and membrane-free protein complexes (Li et al. 2012). We have recently analysed the RNA content of prostasomes isolated from the ejaculate of vasectomized men by deep sequencing and found that the majority is neither mRNA nor miRNA (non-published data).

Prostasomes have also been reported to contain chromosomal DNA, representing an array of small DNA fragments randomly selected from the entire human genome (Ronquist et al. 2009, 2011). In our opinion, however, it cannot be excluded that small apoptotic vesicles, which are known to contain fragmented DNA, were co-isolated with prostasomes.

\section{Sperm cell capacitation and the role of prostasomes}

Sperm cells that are deposited in the female reproductive tract are mature but not yet completely primed for fertilisation. In order to acquire fertilising potential, they first need to undergo a complex series of modifications in a process collectively referred to as capacitation (Bailey 2010, Fraser 2010). During this process, sperm cells attain the capacity to bind to the zona pellucida of the oocyte, are primed to undergo the acrosome reaction and acquire hyperactive motility and the potential to fuse with the oocyte plasma membrane. In vitro, sperm cell capacitation can be initiated by the presence of extracellular bicarbonate, $\mathrm{Ca}^{2+}$ and a cholesterol acceptor such as albumin. Bicarbonate rapidly (within minutes) activates adenylate cyclases, which produce cAMP (Harrison \& Gadella 2005). Sperm cells contain several membrane-associated adenylyl cyclases, as well as a soluble adenylyl cyclase (Esposito et al. 2004). The latter is mainly expressed in the testis and is both $\mathrm{Ca}^{2+}$ and bicarbonate dependent (Buck et al. 1999, Baxendale \& Fraser 2003, Kamenetsky et al. 2006). In a recent study, it was proposed that prostasomes help to increase intracellular CAMP at capacitating conditions (Pons-Rejraji et al. 2011). cAMP stimulates PKA, which is the central activator of several capacitation-related processes in the sperm cell, including a reorganisation of plasma membrane lipid and protein distribution (Harrison \& Miller 2000, Fraser 2010). PKA indirectly stimulates tyrosine phosphorylation of specific sperm proteins, which is considered as a hallmark of capacitation (Visconti et al. 2002, Bailey 2010). Major tyrosinephosphorylated proteins in capacitated human sperm include the PKA anchoring protein AKAP and its precursor, pro-AKAP (Carrera et al. 1996), and their phosphorylation is considered as a terminal stage of capacitation. Others and we have found that prostasomes interfere with end-stage sperm capacitation in vitro, as measured by a decrease in protein tyrosine phosphorylation (Pons-Rejraji et al. 2011, Aalberts et al. 2013). One possible explanation is that cholesterol could be transferred from prostasomes to sperm cells. Another PKA-driven process is plasma membrane lipid scrambling. In non-capacitated sperm cells, lipid asymmetry is maintained by phospholipid transferases: asymmetry is characterized by location of the aminophospholipids PE and phosphatidylserine (PS) predominantly in the inner leaflet of the plasma membrane bilayer, whereas PC and SM are mainly present in the outer leaflet (Harrison \& Gadella 2005). During capacitation, a phospholipid scramblase is activated, resulting in the bi-directional movement of phospholipids across the lipid bilayer. As a result, an increased proportion of PE and PS become exposed on the outer 
leaflet of the sperm cell plasma membrane. This breakdown in membrane asymmetry renders the membrane less stable and enables cholesterol acceptors, such as serum albumin, but probably also lipoproteins, to extract cholesterol from the plasma membrane (Therien et al. 1998, Flesch et al. 2001). Cholesterol extraction leads to a further increase in membrane fluidity, which is associated with a reorganisation of the constituent lipids and proteins and the formation of so-called 'lipid rafts'. Lipid rafts are membrane microdomains that are enriched in cholesterol, sphingolipids and specific membrane proteins, including SNAREs (Chamberlain et al. 2001, Lingwood \& Simons 2010). The function of SNARE proteins is influenced by their position in the membrane rafts. In response to cholesterol removal, the SNARE proteins syntaxin 1 and 2, that reside in the sperm cell plasma membrane, along with the vesicle-associated membrane protein (VAMP), which is located in the outer acrosomal membrane, relocate from their original random distribution over the entire sperm head and become concentrated in the apical ridge area, which is the region of the sperm cell involved in oocyte binding (Tsai et al. 2007).

Sperm cell motility is regulated by intracellular $\mathrm{pH}$ and $\mathrm{Ca}^{2+}$ signalling (Darszon et al. 2011, Alasmari et al. 2013). In most species, sperm cells acquire motility shortly before arrival in the cauda epididymis, immediately after their release from the epididymis or soon after ejaculation. In aqueous solutions, sperm cells with activated motility swim with near linear trajectories as a result of their symmetrical flagellar beats. Within the female reproductive tract, sperm cells presumably migrate through more viscous fluids and interact with cells and cellular projections; most notably, they attach to the mucosal epithelium of the oviduct and, in several mammalian species, oviduct epithelium-bound sperm cells form a reservoir for later fertilisation (Suarez \& Pacey 2006). During sperm hyperactivation, which is physiologically induced during capacitation of sperm within the oviduct, the flagellar movements change in character to large-amplitude, high-frequency and asymmetrical beats. Hyperactivated motility is required for sperm cells to detach from the oviductal epithelium, to swim through the oviductal mucus, pass the layer of follicular cells that surround the oocyte (the cumulus complex) and penetrate the zona pellucida (Quill et al. 2003, Ho et al. 2009). During sperm cell capacitation, the plasma membrane potential becomes hyperpolarised as a consequence of the opening of inwardly rectifying $\mathrm{K}^{+}$channels (Acevedo et al. 2006) and closure of epithelial $\mathrm{Na}^{+}$channels (Hernandez-Gonzalez et al. 2007), which results in the opening of voltagedependent $\mathrm{Ca}^{2+}$ channels (Publicover et al. 2007). Sperm cell hyperactivation is triggered by a sustained $\mathrm{Ca}^{2+}$ influx (Quill et al. 2003). When sperm cells reach the zona pellucida of the oocyte, contact with the zona pellucida, and in particular zona pellucida glycoprotein 3, induces a depolarisation of the sperm plasma membrane (Florman et al. 1998). This depolarisation in turn induces the proton channel, $\mathrm{Hv}_{\mathrm{v}} \mathrm{1}$, in the sperm cell flagellum to open, triggering an outward transport of protons to the extracellular milieu, thereby causing intracellular alkalinisation (Lishko et al. 2010). As a result, sperm-specific pH-dependent CatSper $\mathrm{Ca}^{2+}$ channels are opened (Quill et al. 2003, Kirichok et al. 2006, Neri-Vidaurri Pdel et al. 2006). The initial influx of $\mathrm{Ca}^{2+}$ is thus followed by a sustained $\mathrm{Ca}^{2+}$ entry that requires the presence of the distinct components of the CatSper channel complex (Qi et al. 2007). Opening of the CatSper channels is also stimulated by direct interaction with progesterone, which is released by the cumulus granulosa cells surrounding the oocyte, as well as by prostaglandin $\mathrm{E}_{1}$ and other ligands (Lishko et al. 2011, Strunker et al. 2011, Brenker et al. 2012). In this way, progesterone attracts spermatozoa towards the oocyte and helps them to penetrate the layer of granulosa cells and the zona pellucida. $\mathrm{Ca}^{2+}$ can also be recruited from intracellular $\mathrm{Ca}^{2+}$ storage organelles. Ryanodine receptors are $\mathrm{Ca}^{2+}$ channels that release $\mathrm{Ca}^{2+}$ from such intracellular stores in response to cyclic adenosine dinucleotide phosphate ribose (CADPR) and nicotinic acid adenine dinucleotide phosphate (NAADP) (Park et al. 2011). Increase in intracellular $\mathrm{Ca}^{2+}$ via CatSper channel opening and release of stored $\mathrm{Ca}^{2+}$ at the sperm neck provides two separate mechanisms for regulating motility (Alasmari et al. 2013). Interestingly, long-lasting $\mathrm{Ca}^{2+}$ responses require the presence of prostasomes, and it has therefore been hypothesised that some $\mathrm{Ca}^{2+}$ signalling tools are not initially carried by the sperm cells but have to be delivered to them by prostasomes (Park et al. 2011). Both the ryanodine receptor and CD38, which helps generate CADPR and NAADP, are carried by prostasomes. Similarly, a pump for refilling $\mathrm{Ca}^{2+}$ in intracellular stores, SPCA1, and the plasma membraneassociated progesterone receptor, but not the CatSper elements, are transferred to sperm by prostasomes. Thus, some of the tools required for sustained $\mathrm{Ca}^{2+}$ signalling appear to be transferred to sperm by prostasomes.

\section{The acrosome reaction and prostasomes}

As well as influencing motility, $\mathrm{Ca}^{2+}$ influx also triggers the acrosome reaction in sperm cells. The acrosome is a sperm cell-specific organelle that originates from the Golgi system and is formed during spermiogenesis (Berruti \& Paiardi 2011). The acrosome extends over the anterior aspect of the sperm cell nucleus in the head region and is in close proximity to the sperm plasma membrane. In response to capacitation, trans-SNARE complexes are formed from VAMP3 and syntaxin 1B, in the plasma membrane, and synaptosomal-associated protein 23 (SNAP23) in the outer acrosomal membrane (Tsai et al. 2010, Gadella \& Evans 2011); these complexes hold the two membranes in close proximity. 
During the acrosome reaction, completion of the SNARE interactions results in the outer acrosomal membrane fusing with the overlying plasma membrane. These membrane fusions occur simultaneously at multiple sites, as a consequence of which mixed membrane vesicles are formed, the integrity of the membranes is breached and the acrosomal contents are released. The liberated acrosomal enzymes assist the sperm cell with its penetration through the zona pellucida of the oocyte (Buffone et al. 2008). ZP3 molecules within the zona pellucida are thought to assist in triggering the acrosome reaction (Litscher et al. 2009), probably by activating the Rap guanine nucleotide exchange factors 3 and/or 4, which may induce depolarisation of the sperm cell plasma membrane, thereby stimulating $\mathrm{Ca}^{2+}$ influx (McPartlin et al. 2011). However, while the acrosome reaction can take place at the zona pellucida surface, it is probably initiated even earlier under the influence of cumulus cells, the follicle wall derived epithelial cells that surround the recently ovulated oocyte in the oviduct (Jin et al. 2011). Progesterone secreted by these cells (Therien \& Manjunath 2003), coupled with the previously described transfer of progesterone receptors and other $\mathrm{Ca}^{2+}$ signalling tools by prostasomes (Park etal. 2011), may be important factors in this process.

\section{Prostasomes regulate sperm cell function by first binding and then fusing}

Prostasomes are brought into contact with sperm cells during ejaculation (Fig. 1). As illustrated above, prostasomes have both inhibitory and stimulatory effects on sperm cell function, and their role(s) is therefore complex (Table 1). We recently demonstrated that in vitro recruitment of highly purified prostasomes by live equine sperm cells required the presence of bicarbonate and an environment with $\mathrm{pH} \geq 7.5$, circumstances that also favoured protein tyrosine phosphorylation in sperm cells, a hallmark of capacitation (Aalberts et al. 2013; Fig. 2). By contrast, dead sperm cells 'recruited' prostasomes independently of bicarbonate or $\mathrm{pH}$. Binding specificity was further indicated by the observation that live cells recruited prostasomes primarily at their head region, whereas dead sperm cells recruited prostasomes over both their head and tail regions. A common characteristic of capacitated, and indeed apoptotic or dying, sperm cells is a loss of plasma membrane lipid bilayer asymmetry (Harrison \& Gadella 2005), which might therefore be a requirement for prostasome binding. Notably, however, while prostasomes required capacitating conditions to allow them to bind to live sperm cells, they then reduced the level of tyrosine phosphorylation (Aalberts et al. 2013), consistent with a negative regulatory effect on the progression of capacitation (Pons-Rejraji et al. 2011, Aalberts et al. 2013). How prostasomes inhibit or prevent the progression of capacitation is not known but transfer of cholesterol to the sperm cell's plasma membrane, independent of membrane fusion, is a potential candidate (Cross \& Mahasreshti 1997, Pons-Rejraji et al. 2011). Cholesterol transfer would counteract the cholesterol efflux that normally occurs during in vitro capacitation of washed sperm cells (Cross 1996, Cross \& Mahasreshti 1997). Recent evidence indicates that sterol extraction from sperm cells, a prerequisite for capacitation, depends on the formation of oxysterols in response to low doses of reactive oxygen species (ROS), which in their turn are formed in a bicarbonatedependent process (Boerke et al. 2013). In another study, prostasomes were shown to interfere with ROS production by polymorphonuclear neutrophils from blood or semen (Saez et al. 2000). Although entirely speculative at this point in time, it is therefore possible that prostasomes put a brake on the depletion of cholesterol from the sperm plasma membrane by interfering with sperm cell ROS production. By binding to sperm cells early during capacitation, prostasomes would be in a position to inhibit progression to late capacitation events and therefore help avoid premature induction of the acrosome reaction (Cross \& Mahasreshti 1997, Bechoua et al. 2011, Pons-Rejraji et al. 2011).

The physiological sites for prostasome binding and fusion with sperm cells have not been identified (Fig. 1). In humans, sperm are deposited in the anterior vagina during coitus after which sperm motility helps their passage through the cervical mucus. The acidic environment within the vagina would not be expected to support sperm cell capacitation nor, therefore, the recruitment of

Table 1 Reported effects of prostasomes on sperm cell functions.

\begin{tabular}{ll}
\hline Effects of prostasomes & References \\
\hline Stimulation of early capacitation events & Stegmayr \& Ronquist (1982) and Pons-Rejraji et al. (2011) \\
Inhibition of late capacitation events & Cross \& Mahasreshti (1997), Bechoua et al. (2011), Pons-Rejraji et al. \\
& (2011) and Aalberts et al. (2013) \\
$\begin{array}{l}\text { Inhibition of spontaneous acrosome reaction } \\
\text { Inhibition/stimulation of acrosome reaction dependent }\end{array}$ & Pons-Rejraji et al. (2011) \\
$\begin{array}{c}\text { on environmental conditions } \\
\text { Inhibition/stimulation of motility dependent on } \\
\text { environmental conditions }\end{array}$ & (2008) and Park et al. (2011) \\
Stimulation of fertility & Stegmayr \& Ronquist (1982), Fabiani et al. (1994a, 1994b), Arienti \\
et al. (1999) Bechoua et al. (2011) and Park et al. (2011) \\
\end{tabular}




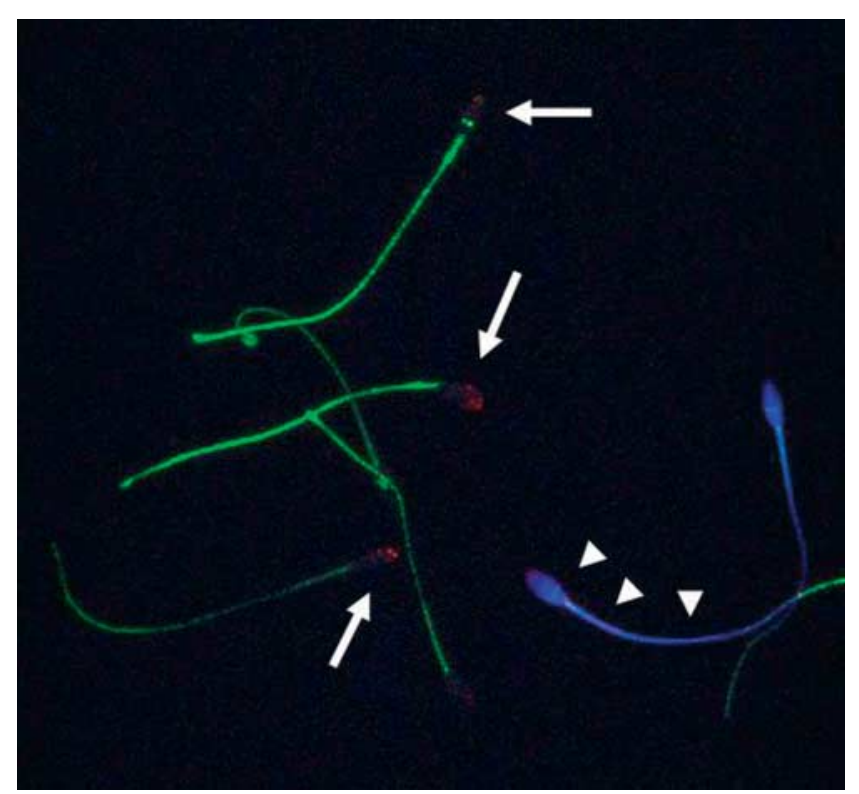

Figure 2 Prostasome binding to capacitated sperm cells. Prostasomes were isolated from stallion semen and labelled with biotin. Washed equine sperm cells were incubated at capacitating conditions (in the presence of $\mathrm{Ca}^{2+}, \mathrm{HCO}_{3}{ }^{-}$and albumin at $\mathrm{pH}$ 7.5) in the presence of biotinylated prostasomes. After selective labelling of dead cells in violet, the cells were fixed, permeabilised and labelled in red with NeutrAvidin for associated biotinylated prostasomes and in green with anti-phosphotyrosine as a marker for capacitation. Cells were imaged by confocal laser scanning microscopy. Prostasomes associated primarily to the sperm head of live capacitated cells, assuming a punctate pattern (arrows). Binding to dead cells was diffuse and not confined to a specific region (arrowheads). For details, see our study (Aalberts et al. 2013).

prostasomes. By contrast, the uterus would be a relatively capacitation-friendly environment, due in part to cystic fibrosis transmembrane conductor regulator (CFTR)-regulated secretion of bicarbonate by the endometrium (Wang et al. 2003). That the uterus should be a physiological site for prostasome recruitment to sperm seems even more obvious for the mammalian species in which semen is deposited intracervically (e.g. the pig) or intrauterine (e.g. the horse). Fusion of previously bound prostasomes to the sperm cells has been reported to occur only in acidic buffers (Arienti et al. 1997 c, Palmerini et al. 1999, Park et al. 2011). The neutral $\mathrm{pH}$ of the uterus and the local presence of bicarbonate would therefore represent a favourable location for prostasome binding but not fusion (Aalberts et al. 2013). We therefore hypothesise that, after binding in the uterus, prostasomes may 'piggy-back' onto the sperm cell's surface to enter the oviduct and accompany the sperm on its final approach to the oocyte-cumulus complex. Here, the role of prostasomes may change as a consequence of fusion with the sperm cells, allowing them to integrate contained cytosolic and membrane constituents into the sperm cell, although definitive proof of fusion at this time is lacking. Stimulatory effects of prostasomes on the acrosome reaction (Palmerini et al. 2003, Siciliano et al. 2008) and sperm motility (Fabiani et al. 1994a, 1994b, 1995, Arienti et al. 1999, Park et al. 2011) have been reported, and as described above, these stimulatory functions can be explained by transfer of $\mathrm{Ca}^{2+}$ signalling tools as a result of the fusion of prostasomes to sperm cells (Park et al. 2011). Whether fusion at this location really occurs and whether it is indeed $\mathrm{pH}$ dependent, along with the nature of a postulated low $\mathrm{pH}$ compartment, are questions that remain to be solved. One possible location is the interstitial space between cumulus cells. The extracellular matrix between cumulus cells is a viscoelastic gel made up of hyaluronic acid containing glycosaminoglycan molecules. Sperm cells traverse this layer with the aid of multiple hyaluronidases (Cherr et al. 2001, Martin-Deleon 2011). In this context, it may be significant that some of these hyaluronidases have a low optimum $\mathrm{pH}$ and are important for sperm penetration of the cumulus. To our knowledge, the $\mathrm{pH}$ of the cumulus interstitial space has never been determined directly, but the requirement for acidic hyaluronidase activity to enable sperm penetration suggests that this could represent a compartment where low $\mathrm{pH}$-induced prostasome fusion may occur. Although entirely hypothetical, such a timely delivery by integration of prostasome borne $\mathrm{Ca}^{2+}$ signalling molecules might explain their apparent facilitatory role in the acrosome reaction. Many in vitro studies have been performed with epididymal sperm cells, which by definition have never been in contact with prostasomes. This may explain some of the controversies in the literature concerning the mechanisms of $\mathrm{Ca}^{2+}$ signalling in sperm cells (Ren 2011). Successful artificial insemination with epididymal sperm has been demonstrated for many species, suggesting that prostatic secretions, and hence the presence of prostasomes, may not be an absolute requirement for successful fertilisation. Studies in the dog, however, showed that addition of prostate fluid to washed ejaculated sperm (Nöthling \& Volkmann 1993) or epididymal sperm (Hori et al. 2005) significantly improved pregnancy and litter size, consistent with a facilitating role of prostasomes.

\section{Prostasomes interact with immune cells}

The female reproductive tract is equipped with a wellbalanced immune system. On the one hand, it has to protect the carrier and a potential embryo or fetus against invading pathogens, but on the other hand, it must tolerate potentially highly immunogenic paternal alloantigens in order to be able to establish and maintain pregnancy (reviewed in Wira et al. (2005) and Hansen (2011)). Macrophages and neutrophil granulocytes form a first line of defence against pathogens but also phagocytose sperm cells (Matthijs et al. 2003, Wira et al. 2005). Natural killer (NK) cells can also attack 
pathogens, while apparently playing an important role during implantation of the embryo and the maintenance of pregnancy (Marlin et al. 2012). Finally, dendritic cells form a bridge between the innate immune system and the adaptive immune system of the female reproductive tract, which also involves T cells (Wira et al. 2005).

In vitro studies have demonstrated that prostasomes have a variety of immunomodulatory capacities. These may involve direct interactions with leukocytes, interactions through the complement system or direct antibacterial or antiviral mechanisms. For example, human prostasomes have been shown to adhere to lymphocytes, inhibit lymphocyte proliferation and to inhibit endocytosis by monocytes and neutrophil granulocytes (Kelly et al. 1991, Skibinski et al. 1992). In the female reproductive tract, inhibition of phagocytotic activity by prostasomes may protect sperm cells from attack by neutrophil granulocytes. Another immunomodulatory property of prostasomes involves inhibition of the generation of superoxide anions by NADPH oxidase in neutrophil granulocytes (Skibinski et al. 1992, Saez et al. 2000). Superoxide anions and other ROS also play a role in the defence by phagocytotic cells against bacteria and fungi. However, the sperm cell is also very sensitive to lipid peroxidation, due to the high content of polyunsaturated fatty acids in its plasma membrane and its limited ROS scavenging capacity as a result of a small cytoplasmic volume. After protein denaturation by heat treatment of the prostasomes, the protective effect against ROS was retained, suggesting that lipids rather than proteins may be involved (Saez et al. 1998). Prostasomes probably do not act as direct scavengers of ROS, unlike other antioxidants in seminal plasma (Tremellen 2008). Instead, prostasomes may modify the plasma membrane of neutrophil granulocytes by transfer of cholesterol and SM to the cells, making them more rigid and resulting in a decrease in NADPH oxidase activity (Lazarevic et al. 1995, Saez et al. 2000). Membrane vesicles from bovine seminal fluid have been demonstrated to have similar effects on proliferation, phagocytotic activity and superoxide production by leukocytes (Lazarevic et al. 1995). Additionally, human prostasomes have been shown to contain CD48, which is the ligand for activating NK cell receptor 2B4 (CD244) (Tarazona et al. 2011). NK cell activity decreases after incubation in the presence of prostasomes, suggesting that prostasomes may also play a role in controlling NK cell activity in the female reproductive tract. In addition, prostasomes have been described to interfere with the complement system, through their surface molecules CD59 and CD46. CD59 is an inhibitor of the membrane attack complex of the complement system. Transfer of CD59 from prostasomes to cells (Rooney et al. 1993, 1996) has been shown to inhibit complement-mediated cell lysis (Babiker et al. 2005). Membrane cofactor protein (CD46) is a transmembrane glycoprotein that possesses cofactor activity for proteolytic inactivation of $\mathrm{C} 3 \mathrm{~b}$ and
C4b of the complement cascade (Kitamura et al. 1995). CD46 is also known as a receptor for measles virus, and prostasomes have been shown to inhibit infectivity of this virus, probably by capture of the virus by CD46, as a kind of 'mock cell' (Kitamura et al. 1995). Another immunomodulatory prostasomal surface protein is galectin-3 (Jones et al. 2010), a $\beta$-galactoside-binding protein that plays a role in immunomodulation, pathogen-host interactions, cell-cell and cell-matrix interactions and cancer progression (Dumic et al. 2006). Galectin-3 lacks a signal sequence for transport into the endoplasmic reticulum and is therefore secreted via a non-classical pathway. The galectin-3 ligand, Mac-2 binding protein (M2BP), has also been found to be associated with prostasomes (Block et al. 2010) and has also been proposed to have an immunomodulatory function on macrophages and monocytes (Block et al. 2010).

Taken together, the interaction of prostasomes with the local female immune system may prevent sperm cells from being phagocytosed, damaged or killed, and thereby prolongs their lifespan in an otherwise hostile environment. Finally, prostasomes have antibacterial properties (Carlsson et al. 2000), probably through the antimicrobial protein human cationic antimicrobial protein-18 (hCAP-18) present in the prostasomal membrane. hCAP-18 belongs to the cathelicidin family and releases the antimicrobial peptide LL37 (Andersson et al. 2002).

\section{Prostasomes and prostate cancer}

Prostate cancer is the most common type of cancer suffered by men in the Western world (Center et al. 2012). As hyperplastic and malignant prostate cells, and even metastatic tumour cells, secrete prostasomes that share many characteristics with prostasomes from normal cells (Carlsson et al. 2003, Sahlen et al. 2004), information on prostasomes may provide valuable information for the early diagnosis of prostate cancer or incipient malignant transformation. While prostasomes are normally secreted from the apical side of the columnar prostate epithelial cells into the glandular lumen and are then excreted in the semen or urine, malignant prostatic epithelial cells become cuboidal and lose polarity. When these cells invade through the basement membrane, prostasomes can be secreted towards the interstitial compartment of the prostate tissue, or even directly into the blood circulation (Sahlen et al. 2002, Ronquist \& Nilsson 2004). Tissues that are normally devoid of prostasomes are now challenged by the immunomodulatory properties of these vesicles, a process that has been proposed to assist tumour survival and metastasis. Moreover, the composition of prostasomes from prostate tumour cells may be altered in several respects, when compared with vesicles from normal prostate cells. 
Characteristics of prostasomes that enable them to influence prostate cancer progression include their involvement in the complement pathway, their expression of enzymes on the prostasomal surface and the promotion of angiogenesis (Ronquist \& Nilsson 2004). As described above, prostasomes contain the complement regulatory proteins CD46 and CD59 and are able to transfer CD59 to neighbouring cells (Kitamura et al. 1995, Babiker et al. 2005). Indeed, prostasomes from malignant cells have a higher ability to transfer CD59 to cells than prostasomes from normal cells (Babiker et al. 2005). Another difference between prostasomes from cancer cells and normal prostate epithelial cells is their enzymatic activity. Prostasomes from cancer cells show a higher kinase activity than prostasomes from normal seminal plasma and thereby enhance ability to phosphorylate complement protein C3 and fibrinogen (Babiker et al. 2006). This makes C3 inaccessible to physiological activation (Forsberg et al. 1990), while it may also alter the functional properties of fibrinogen, a change that has been implicated in cancer cell migration (Simpson-Haidaris \& Rybarczyk 2001). Other enzymes that show a higher activity on prostasomes from tumour cells than normal cells include peptidoglycan hydrolyzing enzymes, matrix metalloproteinases and plasminogen activator, all of which play a role in extracellular matrix degradation and cancer cell invasion (Bellezza et al. 2005). Conversely, the expression of CD26 is reduced on prostate cancer cell-derived prostasomes, which may affect its role as a tumour suppressor (Bellezza et al. 2005). TMPRSS2 is a serine protease that is also expressed on prostasomes (Chen et al. 2010). But while the expression of TMPRSS2 is often dysregulated during prostate cancer due to gene fusion, its function remains unclear.

Membrane vesicles from the prostate cancer cell line DU-145 have been shown to promote the development, invasion and tube formation of endothelial cells (Kim et al. 2002). This is remarkable primarily because prostasomes derived from the seminal fluid of healthy men have been described to conversely inhibit angiogenesis (Delves et al. 2005, 2006). This may indicate that malignant transformation could alter prostasome function with regard to the stimulation of neovascularisation.

To conclude, prostasomes from tumour cells are highly equipped to promote survival of malignantly transformed prostate epithelial cells and tumour progression by inhibiting complement-mediated attack but stimulating invasion into extracellular matrices and neovascularisation. Besides an apparent role in the development and survival of prostate cancer cells, prostasomes from malignant prostate epithelial cells may also serve as a biomarker for this disease (Duijvesz et al. 2011). New biomarkers for prostate cancer would be welcomed because blood serum levels of the currently used and best known prostate cancer marker, PSA, do not always correlate well with the aggressiveness of the malignancy and therefore the prognosis of the condition (Shariat et al. 2011). Qualitative and quantitative analysis of the protein, lipid and/or nucleic acid content of prostasomes may be indicative of prostatic abnormalities. These prostasomes may be isolated from urine or from blood. As the blood of healthy men is normally devoid of prostasomes, secretion of prostasomes into the blood is in itself indicative of pathology. Although EVs from other cell types are present in abundance in the blood, prostasomes could be distinguished using prostate-specific biomarkers. Such markers may be constitutively present in prostasomes from healthy tissue or specific to malignantly transformed prostate epithelial cells. Potential constitutive prostasome-based biomarkers include proteins and RNA. A recent development is a proximity ligation assay, which is based on the simultaneous recognition of four different epitopes by antibodies (Tavoosidana et al. 2011). The antibodies are conjugated to cDNA oligonucleotides, which can hybridise only when the antibodies are in close proximity. Hybridised oligonucleotides can be amplified by a qPCR, thereby allowing specific detection of small quantities of prostasomes ( $\geq 1 \mathrm{ng} / \mathrm{ml}$ ) in patient blood.

\section{Conclusions and future perspectives}

Prostasomes have several special features that characterise them as multifunctional EVs. Prostasomes probably perform these functions within the female reproductive tract by local modulation of the immune system and by associating with sperm cells that find themselves in conditions capable of inducing capacitation, but long before they have encountered the oocyte. The precise physiological roles of distinct classes of prostasomes needs to be resolved and differentiated further, particularly with respect to sperm cell and immune cell modulating functions. In addition, prostasomes are extremely promising candidates as biomarkers (or biomarker carriers) for the diagnosis and/or in prognostication of prostate cancer; this potential needs to be explored further.

\section{Declaration of interest}

The authors declare that there is no conflict of interest that could be perceived as prejudicing the impartiality of the review reported.

\section{Funding}

This review did not receive any specific grant from any funding agency in the public, commercial or not-for-profit sector.

\section{Acknowledgements}

The authors thank Bart Gadella, Federica van Dissel-Emiliani, Richard Wubbolts, Jos Brouwers, Jeroen Brouwers, Edita Sostaric, 
Bernd Helms, Marca Wauben, Esther Nolte 't Hoen and Guillaume van Niel for many stimulating discussions and continuous support. The authors thank Utrecht University for support and funding. The authors apologise to all colleagues whose work could not be cited due to space limitations.

\section{References}

Aalberts $M$, van Dissel-Emiliani FM, van Adrichem NP, van Wijnen $M$, Wauben MH, Stout TA \& Stoorvogel W 2012 Identification of distinct populations of prostasomes that differentially express prostate stem cell antigen, annexin A1, and GLIPR2 in humans. Biology of Reproduction 86 82. (doi:10.1095/biolreprod.111.095760)

Aalberts M, Sostaric E, Wubbolts R, Wauben MW, Nolte-'t Hoen EN, Gadella BM, Stout TA \& Stoorvogel W 2013 Spermatozoa recruit prostasomes in response to capacitation induction. Biochimica et Biophysica Acta 1834 2326-2335. (doi:10.1016/j.bbapap.2012.08.008)

Acevedo JJ, Mendoza-Lujambio I, de la Vega-Beltran JL, Trevino CL, Felix R \& Darszon A $2006 \mathrm{~K}_{\mathrm{ATP}}$ channels in mouse spermatogenic cells and sperm, and their role in capacitation. Developmental Biology 289 395-405. (doi:10.1016/j.ydbio.2005.11.002)

Agrawal Y \& Vanha-Perttula T 1987 Effect of secretory particles in bovine seminal vesicle secretion on sperm motility and acrosome reaction. Journal of Reproduction and Fertility 79 409-419. (doi:10.1530/jrf.0. 0790409)

Alasmari W, Costello S, Correia J, Oxenham SK, Morris J, Fernandes L, Ramalho-Santos J, Kirkman-Brown J, Michelangeli F, Publicover S et al. $2013 \mathrm{Ca}^{2+}$ signals generated by CatSper and $\mathrm{Ca}^{2+}$ stores regulate different behaviors in human sperm. Journal of Biological Chemistry 288 6248-6258. (doi:10.1074/jbc.M112.439356)

Andersson E, Sorensen OE, Frohm B, Borregaard N, Egesten A \& Malm J 2002 Isolation of human cationic antimicrobial protein-18 from seminal plasma and its association with prostasomes. Human Reproduction 17 2529-2534. (doi:10.1093/humrep/17.10.2529)

Arienti G, Carlini E, Verdacchi R, Cosmi EV \& Palmerini CA 1997a Prostasome to sperm transfer of CD13/aminopeptidase N (EC 3.4.11.2). Biochimica et Biophysica Acta 1336 533-538. (doi:10.1016/S03044165(97)00071-8)

Arienti G, Polci A, Carlini E \& Palmerini CA 1997b Transfer of CD26/dipeptidyl peptidase IV (E.C. 3.5.4.4) from prostasomes to sperm. FEBS Letters 410 343-346. (doi:10.1016/S0014-5793(97)00655-8)

Arienti G, Carlini E \& Palmerini CA 1997C Fusion of human sperm to prostasomes at acidic pH. Journal of Membrane Biology 155 89-94. (doi:10.1007/s002329900160)

Arienti G, Carlini E, Polci A, Cosmi EV \& Palmerini CA 1998 Fatty acid pattern of human prostasome lipid. Archives of Biochemistry and Biophysics 358 391-395. (doi:10.1006/abbi.1998.0876)

Arienti G, Carlini E, Nicolucci A, Cosmi EV, Santi F \& Palmerini CA 1999 The motility of human spermatozoa as influenced by prostasomes at various $\mathrm{pH}$ levels. Biology of the Cell 91 51-54.

Arvidson G, Ronquist G, Wikander G \& Ojteg AC 1989 Human prostasome membranes exhibit very high cholesterol/phospholipid ratios yielding high molecular ordering. Biochimica et Biophysica Acta 984 167-173. (doi:10.1016/0005-2736(89)90212-5)

Aumüller G \& Riva A 1992 Morphology and functions of the human seminal vesicle. Andrologia 24 183-196. (doi:10.1111/j.1439-0272.1992. tb02636.x)

Aumüller G \& Seitz J 1990 Protein secretion and secretory processes in male accessory sex glands. International Review of Cytology 121 127-231.

Babiker AA, Nilsson B, Ronquist G, Carlsson L \& Ekdahl KN 2005 Transfer of functional prostasomal CD59 of metastatic prostatic cancer cell origin protects cells against complement attack. Prostate 62 105-114. (doi:10.1002/pros.20102)

Babiker AA, Ronquist G, Nilsson B \& Ekdahl KN 2006 Overexpression of ecto-protein kinases in prostasomes of metastatic cell origin. Prostate $\mathbf{6 6}$ 675-686. (doi:10.1002/pros.20268)

Bailey JL 2010 Factors regulating sperm capacitation. Systems Biology in Reproductive Medicine 56 334-348. (doi:10.3109/19396368.2010. 512377)
Baxendale RW \& Fraser LR 2003 Evidence for multiple distinctly localized adenylyl cyclase isoforms in mammalian spermatozoa. Molecular Reproduction and Development 66 181-189. (doi:10.1002/ mrd.10344)

Bechoua S, Rieu I, Sion B \& Grizard G 2011 Prostasomes as potential modulators of tyrosine phosphorylation in human spermatozoa. Systems Biology in Reproductive Medicine 57 139-148. (doi:10.3109/193 96368.2010.549538)

Bellezza I, Aisa MC, Palazzo R, Costanzi E, Mearini E \& Minelli A 2005 Extracellular matrix degrading enzymes at the prostasome surface. Prostate Cancer and Prostatic Diseases 8 344-348. (doi:10.1038/sj.pcan. 4500828)

Berruti G \& Paiardi C 2011 Acrosome biogenesis: revisiting old questions to yield new insights. Spermatogenesis 1 95-98. (doi:10.4161/spmg.1.2. 16820)

Bjartell A, Montironi R, Berney DM \& Egevad L 2011 Tumour markers in prostate cancer II: diagnostic and prognostic cellular biomarkers. Acta Oncologica 50 (Suppl 1) 76-84. (doi:10.3109/0284186X.2010. 531284)

Block AS, Saraswati S, Lichti CF, Mahadevan M \& Diekman AB 2010 Co-purification of Mac-2 binding protein with galectin-3 and association with prostasomes in human semen. Prostate 15 711-721. (doi:10.1002/ pros.21287)

Boerke A, Brouwers JF, Olkkonen VM, van de Lest $\mathrm{CH}$, Sostaric E, Schoevers EJ, Helms JB \& Gadella BM 2013 Involvement of bicarbonateinduced radical signaling in oxysterol formation and sterol depletion of capacitating mammalian sperm during in vitro fertilization. Biology of Reproduction 88 21. (doi:10.1095/biolreprod.112.101253)

Boonacker E \& Van Noorden CJ 2003 The multifunctional or moonlighting protein CD26/DPPIV. European Journal of Cell Biology 82 53-73. (doi:10.1078/0171-9335-00302)

Brenker C, Goodwin N, Weyand I, Kashikar ND, Naruse M, Krahling M, Muller A, Kaupp UB \& Strunker T 2012 The CatSper channel: a polymodal chemosensor in human sperm. EMBO Journal 31 1654-1665. (doi:10.1038/emboj.2012.30)

Brody I, Ronquist G \& Gottfries A 1983 Ultrastructural localization of the prostasome - an organelle in human seminal plasma. Upsala Journal of Medical Sciences 88 63-80. (doi:10.3109/03009738309178440)

Brouwers JF, Aalberts M, Jansen JW, van Niel G, Wauben MH, Stout TA, Helms JB \& Stoorvogel W 2013 Distinct lipid compositions of two types of human prostasomes. Proteomics 13 1660-1666. (doi:10.1002/pmic. 201200348)

Buck J, Sinclair ML, Schapal L, Cann MJ \& Levin LR 1999 Cytosolic adenylyl cyclase defines a unique signaling molecule in mammals. PNAS 96 79-84. (doi:10.1073/pnas.96.1.79)

Buffone MG, Foster JA \& Gerton GL 2008 The role of the acrosomal matrix in fertilization. International Journal of Developmental Biology $\mathbf{5 2}$ 511-522. (doi:10.1387/ijdb.072532mb)

Carlini E, Palmerini CA, Cosmi EV \& Arienti G 1997 Fusion of sperm with prostasomes: effects on membrane fluidity. Archives of Biochemistry and Biophysics 343 6-12. (doi:10.1006/abbi.1997.9999)

Carlsson L, Pahlson C, Bergquist M, Ronquist G \& Stridsberg M 2000 Antibacterial activity of human prostasomes. Prostate 44 279-286. (doi:10.1002/1097-0045(20000901)44:4<279::AID-PROS4>3.0. $\mathrm{CO} ; 2-2)$

Carlsson L, Nilsson O, Larsson A, Stridsberg M, Sahlen G \& Ronquist G 2003 Characteristics of human prostasomes isolated from three different sources. Prostate 54 322-330. (doi:10.1002/pros.10189)

Carlsson L, Ronquist G, Eliasson R, Egberg N \& Larsson A 2006 Flow cytometric technique for determination of prostasomal quantity, size and expression of CD10, CD13, CD26 and CD59 in human seminal plasma. International Journal of Andrology 29 331-338. (doi:10.1111/j.13652605.2005.00601.x)

Carrera A, Moos J, Ning XP, Gerton GL, Tesarik J, Kopf GS \& Moss SB 1996 Regulation of protein tyrosine phosphorylation in human sperm by a calcium/calmodulin-dependent mechanism: identification of A kinase anchor proteins as major substrates for tyrosine phosphorylation. Developmental Biology 180 284-296. (doi:10.1006/dbio.1996.0301)

Center MM, Jemal A, Lortet-Tieulent J, Ward E, Ferlay J, Brawley O \& Bray F 2012 International variation in prostate cancer incidence and mortality rates. European Urology 61 1079-1092. (doi:10.1016/j.eururo. 2012.02.054) 
Chamberlain LH, Burgoyne RD \& Gould GW 2001 SNARE proteins are highly enriched in lipid rafts in PC12 cells: implications for the spatial control of exocytosis. PNAS 98 5619-5624. (doi:10.1073/pnas. 091502398)

Chen YW, Lee MS, Lucht A, Chou FP, Huang W, Havighurst TC, Kim K, Wang JK, Antalis TM, Johnson MD et al. 2010 TMPRSS2, a serine protease expressed in the prostate on the apical surface of luminal epithelial cells and released into semen in prostasomes, is misregulated in prostate cancer cells. American Journal of Pathology 176 2986-2996. (doi:10.2353/ajpath.2010.090665)

Cherr GN, Yudin Al \& Overstreet JW 2001 The dual functions of $\mathrm{GPI}-$ anchored $\mathrm{PH}-20$ : hyaluronidase and intracellular signaling. Matrix Biology 20 515-525. (doi:10.1016/S0945-053X(01)00171-8)

Cho SY, Choi K, Jeon JH, Kim CW, Shin DM, Lee JB, Lee SE, Kim CS, Park JS, Jeong EM et al. 2010 Differential alternative splicing of human transglutaminase 4 in benign prostate hyperplasia and prostate cancer. Experimental \& Molecular Medicine 42 310-318. (doi:10.3858/emm. 2010.42.4.031)

Chughtai B, Sawas A, O'Malley RL, Naik RR, Ali Khan S \& Pentyala S 2005 A neglected gland: a review of Cowper's gland. International Journal of Andrology 28 74-77. (doi:10.1111/j.1365-2605.2005.00499.x)

Cooper TG 1998 Interactions between epididymal secretions and spermatozoa. Journal of Reproduction and Fertility. Supplement $\mathbf{5 3}$ 119-136.

Cornwall GA 2009 New insights into epididymal biology and function. Human Reproduction Update 15 213-227. (doi:10.1093/humupd/ dmn055)

Cross NL 1996 Human seminal plasma prevents sperm from becoming acrosomally responsive to the agonist, progesterone: cholesterol is the major inhibitor. Biology of Reproduction 54 138-145. (doi:10.1095/ biolreprod54.1.138)

Cross NL \& Mahasreshti P 1997 Prostasome fraction of human seminal plasma prevents sperm from becoming acrosomally responsive to the agonist progesterone. Archives of Andrology 39 39-44. (doi:10.3109/ 01485019708987900)

Darszon A, Nishigaki T, Beltran C \& Trevino CL 2011 Calcium channels in the development, maturation, and function of spermatozoa. Physiological Reviews 91 1305-1355. (doi:10.1152/physrev.00028.2010)

Delves GH, Stewart AB, Lwaleed BA \& Cooper AJ 2005 In vitro inhibition of angiogenesis by prostasomes. Prostate Cancer and Prostatic Diseases 8 174-178. (doi:10.1038/sj.pcan.4500790)

Delves GH, Goyal A, Lwaleed BA \& Cooper AJ 2006 Seminal prostasomes inhibit the angiogenesis activity of rat aortic rings. Prostate Cancer and Prostatic Diseases 9 444-447. (doi:10.1038/sj.pcan.4500896)

Dubois V, Van Ginneken C, De Cock H, Lambeir AM, Van der Veken P, Augustyns K, Chen X, Scharpe S \& De Meester I 2009 Enzyme activity and immunohistochemical localization of dipeptidyl peptidase 8 and 9 in male reproductive tissues. Journal of Histochemistry and Cytochemistry 57 531-541. (doi:10.1369/jhc.2009.952739)

Duijvesz D, Luider T, Bangma CH \& Jenster G 2011 Exosomes as biomarker treasure chests for prostate cancer. European Urology 59 823-831. (doi:10.1016/j.eururo.2010.12.031)

Dumic J, Dabelic S \& Flogel M 2006 Galectin-3: an open-ended story. Biochimica et Biophysica Acta 1760 616-635. (doi:10.1016/j.bbagen. 2005.12.020)

Duncan MW \& Thompson HS 2007 Proteomics of semen and its constituents. Proteomics. Clinical Applications 1 861-875. (doi:10.1002/ prca.200700228)

Esposito G, Jaiswal BS, Xie F, Krajnc-Franken MA, Robben TJ, Strik AM, Kuil C, Philipsen RL, van Duin M, Conti M et al. 2004 Mice deficient for soluble adenylyl cyclase are infertile because of a severe sperm-motility defect. PNAS 101 2993-2998. (doi:10.1073/pnas.0400050101)

Fabiani R \& Ronquist G 1993 Characteristics of membrane-bound 5'-nucleotidase on human prostasomes. Clinica Chimica Acta 216 175-182. (doi:10.1016/0009-8981(93)90150-3)

Fabiani R \& Ronquist G 1995 Association of some hydrolytic enzymes with the prostasome membrane and their differential responses to detergent and PIPLC treatment. Prostate 27 95-101. (doi:10.1002/pros. 2990270206)

Fabiani R, Johansson L, Lundkvist O \& Ronquist G 1994a Enhanced recruitment of motile spermatozoa by prostasome inclusion in swim-up medium. Human Reproduction 9 1485-1489.
Fabiani R, Johansson L, Lundkvist O, Ulmsten U \& Ronquist G $1994 b$ Promotive effect by prostasomes on normal human spermatozoa exhibiting no forward motility due to buffer washings. European Journal of Obstetrics, Gynecology, and Reproductive Biology 57 181-188. (doi:10.1016/0028-2243(94)90298-4)

Fabiani R, Johansson L, Lundkvist O \& Ronquist G 1995 Prolongation and improvement of prostasome promotive effect on sperm forward motility. European Journal of Obstetrics, Gynecology, and Reproductive Biology 58 191-198.

Flesch FM, Brouwers JF, Nievelstein PF, Verkleij AJ, van Golde LM, Colenbrander B \& Gadella BM 2001 Bicarbonate stimulated phospholipid scrambling induces cholesterol redistribution and enables cholesterol depletion in the sperm plasma membrane. Journal of Cell Science 114 3543-3555.

Florman HM, Arnoult C, Kazam IG, Li C \& O'Toole CM 1998 A perspective on the control of mammalian fertilization by egg-activated ion channels in sperm: a tale of two channels. Biology of Reproduction 59 12-16. (doi:10.1095/biolreprod59.1.12)

Forsberg PO, Martin SC, Nilsson B, Ekman P, Nilsson UR \& Engstrom L 1990 In vitro phosphorylation of human complement factor C3 by protein kinase $\mathrm{A}$ and protein kinase $\mathrm{C}$. Effects on the classical and alternative pathways. Journal of Biological Chemistry 265 2941-2946.

Fraser LR 2010 The "switching on" of mammalian spermatozoa: molecular events involved in promotion and regulation of capacitation. Molecular Reproduction and Development 77 197-208. (doi:10.1002/mrd.21124)

Frenette G \& Sullivan R 2001 Prostasome-like particles are involved in the transfer of P25b from the bovine epididymal fluid to the sperm surface. Molecular Reproduction and Development 59 115-121. (doi:10.1002/ mrd.1013)

Frenette G, Lessard C \& Sullivan R 2002 Selected proteins of "prostasomelike particles" from epididymal cauda fluid are transferred to epididymal caput spermatozoa in bull. Biology of Reproduction 67 308-313. (doi:10.1095/biolreprod67.1.308)

Frenette G, Thabet M \& Sullivan R 2006 Polyol pathway in human epididymis and semen. Journal of Andrology 27 233-239. (doi:10.2164/ jandrol.05108)

Gadella BM \& Evans JP 2011 Membrane fusions during mammalian fertilization. Advances in Experimental Medicine and Biology 713 65-80. (doi:10.1007/978-94-007-0763-4_5)

Gaudreault C, Le gare C, Berube B \& Sullivan R 1999 Hamster sperm protein, p26h: a member of the short-chain dehydrogenase/reductase superfamily. Biology of Reproduction 61 264-273. (doi:10.1095/ biolreprod61.1.264)

Girouard J, Frenette G \& Sullivan R 2011 Comparative proteome and lipid profiles of bovine epididymosomes collected in the intraluminal compartment of the caput and cauda epididymidis. International Journal of Andrology 34 e475-e486. (doi:10.1111/j.1365-2605.2011. 01203.x)

Graddis TJ, McMahan CJ, Tamman J, Page KJ \& Trager JB 2011 Prostatic acid phosphatase expression in human tissues. International Journal of Clinical and Experimental Pathology 4 295-306.

Hansen PJ 2011 The immunology of early pregnancy in farm animals. Reproduction in Domestic Animals 46 (Suppl 3) 18-30. (doi:10.1111/ j.1439-0531.2011.01850.x)

Harrison RA \& Gadella BM 2005 Bicarbonate-induced membrane processing in sperm capacitation. Theriogenology 63 342-351. (doi:10.1016/j.theriogenology.2004.09.016)

Harrison RA \& Miller NG 2000 cAMP-dependent protein kinase control of plasma membrane lipid architecture in boar sperm. Molecular Reproduction and Development 55 220-228. (doi:10.1002/(SICI)10982795(200002)55:2 <220::AID-MRD12 > 3.0.CO;2-I)

Hernandez-Gonzalez EO, Trevino CL, Castellano LE, de la Vega-Beltran JL, Ocampo AY, Wertheimer E, Visconti PE \& Darszon A 2007 Involvement of cystic fibrosis transmembrane conductance regulator in mouse sperm capacitation. Journal of Biological Chemistry 282 24397-24406. (doi:10.1074/jbc.M701603200)

Ho K, Wolff CA \& Suarez SS 2009 CatSper-null mutant spermatozoa are unable to ascend beyond the oviductal reservoir. Reproduction, Fertility, and Development 21 345-350. (doi:10.1071/RD08183)

Hori T, Hagiuda K, Kawakami E \& Tsutsui T 2005 Unilateral intrauterine insemination with prostatic fluid-sensitized frozen caudal epididymal sperm in beagle dogs. Theriogenology 63 1573-1583. 
Jansen FH, Krijgsveld J, van Rijswijk A, van den Bemd GJ, van den Berg MS, van Weerden WM, Willemsen R, Dekker LJ, Luider TM \& Jenster G 2009 Exosomal secretion of cytoplasmic prostate cancer xenograft-derived proteins. Molecular and Cellular Proteomics 8 1192-1205. (doi:10. 1074/mcp.M800443-MCP200)

Jin M, Fujiwara E, Kakiuchi Y, Okabe M, Satouh Y, Baba SA, Chiba K \& Hirohashi N 2011 Most fertilizing mouse spermatozoa begin their acrosome reaction before contact with the zona pellucida during in vitro fertilization. PNAS 108 4892-4896. (doi:10.1073/pnas.1018202108)

Jones JL, Saraswati S, Block AS, Lichti CF, Mahadevan M \& Diekman AB 2010 Galectin-3 is associated with prostasomes in human semen. Glycoconjugate Journal 27 227-236. (doi:10.1007/s10719-009-9262-9)

Kamenetsky M, Middelhaufe S, Bank EM, Levin LR, Buck J \& Steegborn C 2006 Molecular details of cAMP generation in mammalian cells: a tale of two systems. Journal of Molecular Biology 362 623-639. (doi:10.1016/ j.jmb.2006.07.045)

Kelly RW, Holland P, Skibinski G, Harrison C, McMillan L, Hargreave T \& James K 1991 Extracellular organelles (prostasomes) are immunosuppressive components of human semen. Clinical and Experimental Immunology 86 550-556. (doi:10.1111/j.1365-2249.1991.tb02968.x)

Kim CW, Lee HM, Lee TH, Kang C, Kleinman HK \& Gho YS 2002 Extracellular membrane vesicles from tumor cells promote angiogenesis via sphingomyelin. Cancer Research 62 6312-6317.

Kirichok Y, Navarro B \& Clapham DE 2006 Whole-cell patch-clamp measurements of spermatozoa reveal an alkaline-activated $\mathrm{Ca}^{2+}$ channel. Nature 439 737-740. (doi:10.1038/nature04417)

Kitamura M, Namiki M, Matsumiya K, Tanaka K, Matsumoto M, Hara T, Kiyohara H, Okabe M, Okuyama A \& Seya T 1995 Membrane cofactor protein (CD46) in seminal plasma is a prostasome-bound form with complement regulatory activity and measles virus neutralizing activity. Immunology 84 626-632.

Lamontagne N, Legare C, Gaudreault C \& Sullivan R 2001 Identification and characterization of $\mathrm{P} 31 \mathrm{~m}$, a novel sperm protein in Cynomolgus monkey (Macaca fascicularis). Molecular Reproduction and Development 59 431-441. (doi:10.1002/mrd.1050)

Laxman B, Morris DS, Yu J, Siddiqui J, Cao J, Mehra R, Lonigro RJ, Tsodikov A, Wei JT, Tomlins SA et al. 2008 A first-generation multiplex biomarker analysis of urine for the early detection of prostate cancer. Cancer Research 68 645-649. (doi:10.1158/0008-5472.CAN07-3224)

Lazarevic M, Skibinski G, Kelly RW \& James K 1995 Immunomodulatory effects of extracellular secretory vesicles isolated from bovine semen. Veterinary Immunology and Immunopathology 44 237-250. (doi:10. 1016/0165-2427(94)05320-R)

Legare C, Gaudreault C, St-Jacques S \& Sullivan R 1999 P34H sperm protein is preferentially expressed by the human corpus epididymidis. Endocrinology 140 3318-3327. (doi:10.1210/en.140.7.3318)

Leyten GH, Hessels D, Jannink SA, Smit FP, de Jong H, Cornel EB, de Reijke TM, Vergunst H, Kil P, Knipscheer BC et al. 2012 Prospective multicentre evaluation of PCA3 and TMPRSS2-ERG gene fusions as diagnostic and prognostic urinary biomarkers for prostate cancer. European Urology pii: S0302-2838(12)01345-0. [Epub ahead of print]. (doi:10.1016/j.eururo.2012.11.014)

Li H, Huang S, Guo C, Guan H \& Xiong C 2012 Cell-free seminal mRNA and microRNA exist in different forms. PLoS ONE 7 e34566. (doi:10.1371/journal.pone.0034566)

Lingwood D \& Simons K 2010 Lipid rafts as a membrane-organizing principle. Science 327 46-50. (doi:10.1126/science.1174621)

Lishko PV, Botchkina IL, Fedorenko A \& Kirichok Y 2010 Acid extrusion from human spermatozoa is mediated by flagellar voltage-gated proton channel. Cell 140 327-337. (doi:10.1016/j.cell.2009.12.053)

Lishko PV, Botchkina IL \& Kirichok Y 2011 Progesterone activates the principal $\mathrm{Ca}^{2+}$ channel of human sperm. Nature 471 387-391. (doi:10. 1038/nature09767)

Litscher ES, Williams Z \& Wassarman PM 2009 Zona pellucida glycoprotein ZP3 and fertilization in mammals. Molecular Reproduction and Development 76 933-941. (doi:10.1002/mrd.21046)

Llorente A, de Marco MC \& Alonso MA 2004 Caveolin-1 AL are located on prostasomes secreted by the prostate cancer PC-3 cell line. Journal of Cell Science 117 5343-5351. (doi:10.1242/jcs.01420)
Llorente A, van Deurs B \& Sandvig K 2007 Cholesterol regulates prostasome release from secretory lysosomes in PC-3 human prostate cancer cells. European Journal of Cell Biology 86 405-415. (doi:10. 1016/j.ejcb.2007.05.001)

Manin M, Lecher P, Martinez A, Tournadre S \& Jean C 1995 Exportation of mouse vas deferens protein, a protein without a signal peptide, from mouse vas deferens epithelium: a model of apocrine secretion. Biology of Reproduction 52 50-62. (doi:10.1095/biolreprod52.1.50)

Marlin R, Duriez M, Berkane N, de Truchis C, Madec Y, Rey-Cuille MA, Cummings JS, Cannou C, Quillay H, Barre-Sinoussi F et al. 2012 Dynamic shift from CD85j/ILT-2 to NKG2D NK receptor expression pattern on human decidual NK during the first trimester of pregnancy. PLOS ONE 7 e30017. (doi:10.1371/journal.pone.0030017)

Martin-Deleon PA 2011 Germ-cell hyaluronidases: their roles in sperm function. International Journal of Andrology 34 e306-e318. (doi:10. 1111/j.1365-2605.2010.01138.x)

Matthijs A, Engel B \& Woelders H 2003 Neutrophil recruitment and phagocytosis of boar spermatozoa after artificial insemination of sows, and the effects of inseminate volume, sperm dose and specific additives in the extender. Reproduction 125 357-367. (doi:10.1530/rep.0. 1250357)

McPartlin LA, Visconti PE \& Bedford-Guaus SJ 2011 Guanine-nucleotide exchange factors (RAPGEF3/RAPGEF4) induce sperm membrane depolarization and acrosomal exocytosis in capacitated stallion sperm. Biology of Reproduction 85 179-188. (doi:10.1095/biolreprod.110. 085555)

Mina-Osorio P 2008 The moonlighting enzyme CD13: old and new functions to target. Trends in Molecular Medicine 14 361-371. (doi:10. 1016/j.molmed.2008.06.003)

Minelli A, Allegrucci C, Liguori L \& Ronquist G 2002 Ecto-diadenosine polyphosphates hydrolase activity on human prostasomes. Prostate $\mathbf{5 1}$ 1-9. (doi:10.1002/pros.10062)

Neri-Vidaurri Pdel C, Torres-Flores V \& Gonzalez-Martinez MT 2006 A remarkable increase in the $\mathrm{pHi}$ sensitivity of voltage-dependent calcium channels occurs in human sperm incubated in capacitating conditions. Biochemical and Biophysical Research Communications 343 105-109. (doi:10.1016/j.bbrc.2006.02.095)

Nilsson J, Skog J, Nordstrand A, Baranov V, Mincheva-Nilsson L, Breakefield XO \& Widmark A 2009 Prostate cancer-derived urine exosomes: a novel approach to biomarkers for prostate cancer. British Journal of Cancer 100 1603-1607. (doi:10.1038/sj.bjc.6605058)

Nistal M, Santamaria L \& Paniagua R 1992 The ampulla of the ductus deferens in man: morphological and ultrastructural aspects. Journal of Anatomy 180 97-104.

Nöthling JO \& Volkmann DH 1993 Effect of addition of autologous prostatic fluid on the fertility of frozen-thawed dog semen after intravaginal insemination. Journal of Reproduction and Fertility Supplement $\mathbf{4 7}$ 329-333.

Oh JS, Han C \& Cho C 2009 ADAM7 is associated with epididymosomes and integrated into sperm plasma membrane. Molecules and Cells $\mathbf{2 8}$ 441-446. (doi:10.1007/s10059-009-0140-x)

Palmerini CA, Carlini E, Nicolucci A \& Arienti G 1999 Increase of human spermatozoa intracellular $\mathrm{Ca}^{2+}$ concentration after fusion with prostasomes. Cell Calcium 25 291-296. (doi:10.1054/ceca.1999.0031)

Palmerini CA, Saccardi C, Carlini E, Fabiani R \& Arienti G 2003 Fusion of prostasomes to human spermatozoa stimulates the acrosome reaction. Fertility and Sterility 80 1181-1184. (doi:10.1016/S00150282(03)02160-5)

Park KH, Kim BJ, Kang J, Nam TS, Lim JM, Kim HT, Park JK, Kim YG, Chae SW \& Kim UH $2011 \mathrm{Ca}^{2+}$ signaling tools acquired from prostasomes are required for progesterone-induced sperm motility. Science Signaling 4 ra31. (doi:10.1126/scisignal.2001595)

Poliakov A, Spilman M, Dokland T, Amling CL \& Mobley JA 2009 Structural heterogeneity and protein composition of exosome-like vesicles (prostasomes) in human semen. Prostate 69 159-167. (doi:10.1002/ pros.20860)

Pons-Rejraji H, Artonne C, Sion B, Brugnon F, Canis M, Janny L \& Grizard G 2011 Prostasomes: inhibitors of capacitation and modulators of cellular signalling in human sperm. International Journal of Andrology 34 568-580. (doi:10.1111/j.1365-2605.2010.01116.x) 
Publicover S, Harper CV \& Barratt C $2007\left[\mathrm{Ca}^{2+}\right]_{\mathrm{i}}$ signalling in sperm making the most of what you've got. Nature Cell Biology 9 235-242. (doi:10.1038/ncb0307-235)

Qi H, Moran MM, Navarro B, Chong JA, Krapivinsky G, Krapivinsky L, Kirichok Y, Ramsey IS, Quill TA \& Clapham DE 2007 All four CatSper ion channel proteins are required for male fertility and sperm cell hyperactivated motility. PNAS 104 1219-1223. (doi:10.1073/pnas. 0610286104

Quill TA, Sugden SA, Rossi KL, Doolittle LK, Hammer RE \& Garbers DL 2003 Hyperactivated sperm motility driven by CatSper2 is required for fertilization. PNAS 100 14869-14874. (doi:10.1073/pnas.2136654100)

Raposo G \& Stoorvogel W 2013 Extracellular vesicles: exosomes, microvesicles, and friends. Journal of Cell Biology 200 373-383. (doi:10.1083/jcb.201211138)

Ren D 2011 Calcium signaling in sperm: help from prostasomes. Science Signaling 4 pe27. (doi:10.1126/scisignal.2002102)

Renneberg H, Albrecht M, Kurek R, Krause E, Lottspeich F, Aumuller G \& Wilhelm B 2001 Identification and characterization of neutral endopeptidase (EC 3, 4. 24. 11) from human prostasomes - localization in prostatic tissue and cell lines. Prostate 46 173-183. (doi:10.1002/10970045(20010215)46:3 < 173::AID-PROS1021 > 3.0.CO;2-F)

Ronquist G 2012 Prostasomes are mediators of intercellular communication: from basic research to clinical implications. Journal of Internal Medicine 271 400-413. (doi:10.1111/j.1365-2796.2011.02487.x)

Ronquist G \& Brody I 1985 The prostasome: its secretion and function in man. Biochimica et Biophysica Acta 822 203-218. (doi:10.1016/03044157(85)90008-5)

Ronquist G \& Hedstrom M 1977 Restoration of detergent-inactivated adenosine triphosphatase activity of human prostatic fluid with concanavalin A. Biochimica et Biophysica Acta 483 483-486. (doi:10. 1016/0005-2744(77)90078-X)

Ronquist G \& Nilsson BO 2004 The Janus-faced nature of prostasomes: their pluripotency favours the normal reproductive process and malignant prostate growth. Prostate Cancer and Prostatic Diseases 7 21-31. (doi:10. 1038/sj.pcan.4500684)

Ronquist G, Brody I, Gottfries A \& Stegmayr B 1978a $\mathrm{An} \mathrm{Mg}^{2+}$ and $\mathrm{Ca}^{2+}$ stimulated adenosine triphosphatase in human prostatic fluid: part I. Andrologia 10 261-272. (doi:10.1111/j.1439-0272.1978.tb03030.x)

Ronquist G, Brody I, Gottfries A \& Stegmayr B $1978 b \mathrm{An} \mathrm{Mg}^{2+}$ and $\mathrm{Ca}^{2+}$ stimulated adenosine triphosphatase in human prostatic fluid-part II. Andrologia 10 427-433. (doi:10.1111/j.1439-0272.1978.tb03064.x)

Ronquist KG, Ronquist G, Carlsson L \& Larsson A 2009 Human prostasomes contain chromosomal DNA. Prostate 69 737-743. (doi:10.1002/pros.20921)

Ronquist GK, Larsson A, Ronquist G, Isaksson A, Hreinsson J, Carlsson L \& Stavreus-Evers A 2011 Prostasomal DNA characterization and transfer into human sperm. Molecular Reproduction and Development 78 467-476. (doi:10.1002/mrd.21327)

Rooney IA, Atkinson JP, Krul ES, Schonfeld G, Polakoski K, Saffitz JE \& Morgan BP 1993 Physiologic relevance of the membrane attack complex inhibitory protein CD59 in human seminal plasma: CD59 is present on extracellular organelles (prostasomes), binds cell membranes, and inhibits complement-mediated lysis. Journal of Experimental Medicine 177 1409-1420. (doi:10.1084/jem.177.5.1409)

Rooney IA, Heuser JE \& Atkinson JP 1996 GPI-anchored complement regulatory proteins in seminal plasma. An analysis of their physical condition and the mechanisms of their binding to exogenous cells. Journal of Clinical Investigation 97 1675-1686. (doi:10.1172/ JCI118594)

Saez F, Motta C, Boucher D \& Grizard G 1998 Antioxidant capacity of prostasomes in human semen. Molecular Human Reproduction $\mathbf{4}$ 667-672. (doi:10.1093/molehr/4.7.667)

Saez F, Motta C, Boucher D \& Grizard G 2000 Prostasomes inhibit the NADPH oxidase activity of human neutrophils. Molecular Human Reproduction 6 883-891. (doi:10.1093/molehr/6.10.883)

Sahlen GE, Egevad L, Ahlander A, Norlen BJ, Ronquist G \& Nilsson BO 2002 Ultrastructure of the secretion of prostasomes from benign and malignant epithelial cells in the prostate. Prostate 53 192-199. (doi:10. 1002/pros.10126)

Sahlen G, Ahlander A, Frost A, Ronquist G, Norlen BJ \& Nilsson BO 2004 Prostasomes are secreted from poorly differentiated cells of prostate cancer metastases. Prostate 61 291-297. (doi:10.1002/pros.20090)
Sahlen G, Nilsson O, Larsson A, Carlsson L, Norlen BJ \& Ronquist G 2010 Secretions from seminal vesicles lack characteristic markers for prostasomes. Upsala Journal of Medical Sciences 115 107-112. (doi:10.3109/03009730903366067)

Schwarz A, Wennemuth G, Post H, Brandenburger T, Aumuller G \& Wilhelm B 2013 Vesicular transfer of membrane components to bovine epididymal spermatozoa. Cell and Tissue Research 353 549-561. (doi:10.1007/s00441-013-1633-7)

Shariat SF, Semjonow A, Lilja H, Savage C, Vickers AJ \& Bjartell A 2011 Tumor markers in prostate cancer I: blood-based markers. Acta Oncologica 50 (Suppl 1) 61-75. (doi:10.3109/0284186X.2010.542174)

Shoji-Kawata S, Sumpter R, Leveno M, Campbell GR, Zou Z, Kinch L, Wilkins AD, Sun Q, Pallauf K, MacDuff D et al. 2013 Identification of a candidate therapeutic autophagy-inducing peptide. Nature $\mathbf{4 9 4}$ 201-206. (doi:10.1038/nature11866)

Siciliano L, Marciano V \& Carpino A 2008 Prostasome-like vesicles stimulate acrosome reaction of pig spermatozoa. Reproductive Biology and Endocrinology 6 5. (doi:10.1186/1477-7827-6-5)

Simpson-Haidaris PJ \& Rybarczyk B 2001 Tumors and fibrinogen. The role of fibrinogen as an extracellular matrix protein. Annals of the New York Academy of Sciences 936 406-425. (doi:10.1111/j.1749-6632.2001. tb03525.x)

Skibinski G, Kelly RW, Harkiss D \& James K 1992 Immunosuppression by human seminal plasma - extracellular organelles (prostasomes) modulate activity of phagocytic cells. American Journal of Reproductive Immunology 28 97-103. (doi:10.1111/j.1600-0897.1992.tb00767.x)

Stegmayr B \& Ronquist G 1982 Stimulation of sperm progressive motility by organelles in human seminal plasma. Scandinavian Journal of Urology and Nephrology 16 85-90. (doi:10.3109/00365598209179734)

Strunker T, Goodwin N, Brenker C, Kashikar ND, Weyand I, Seifert R \& Kaupp UB 2011 The CatSper channel mediates progesterone-induced $\mathrm{Ca}^{2+}$ influx in human sperm. Nature 471 382-386. (doi:10.1038/ nature09769)

Suarez SS \& Pacey AA 2006 Sperm transport in the female reproductive tract. Human Reproduction Update 12 23-37. (doi:10.1093/humupd/ dmi047)

Subiran N, Agirregoitia E, Valdivia A, Ochoa C, Casis L \& Irazusta J 2007 Expression of enkephalin-degrading enzymes in human semen and implications for sperm motility. Fertility and Sterility 89 1571-1577. (doi:10.1016/j.fertnstert.2007.06.056)

Sullivan R \& Saez F 2013 Epididymosomes, prostasomes, and liposomes: their roles in mammalian male reproductive physiology. Reproduction 146 R21-R35. (doi:10.1530/REP-13-0058)

Sun GH, Lin YC, Guo YW, Chang SY \& Liu HW 2000 Purification of GP-83, a glycoprotein secreted by the human epididymis and conjugated to mature spermatozoa. Molecular Human Reproduction 6 429-434. (doi:10.1093/molehr/6.5.429)

Tarazona R, Delgado E, Guarnizo MC, Roncero RG, Morgado S, SanchezCorrea B, Gordillo JJ, Dejulian J \& Casado JG 2011 Human prostasomes express CD48 and interfere with NK cell function. Immunobiology 216 41-46. (doi:10.1016/j.imbio.2010.03.002)

Tavoosidana G, Ronquist G, Darmanis S, Yan J, Carlsson L, Wu D, Conze T, Ek P, Semjonow A, Eltze E et al. 2011 Multiple recognition assay reveals prostasomes as promising plasma biomarkers for prostate cancer. PNAS 108 8809-8814. (doi:10.1073/pnas.1019330108)

Therien I \& Manjunath P 2003 Effect of progesterone on bovine sperm capacitation and acrosome reaction. Biology of Reproduction 69 1408-1415. (doi:10.1095/biolreprod.103.017855)

Therien I, Moreau R \& Manjunath P 1998 Major proteins of bovine seminal plasma and high-density lipoprotein induce cholesterol efflux from epididymal sperm. Biology of Reproduction 59 768-776. (doi:10.1095/ biolreprod59.4.768)

Tosoian J \& Loeb S 2010 PSA and beyond: the past, present, and future of investigative biomarkers for prostate cancer. Scientific World Journal 10 1919-1931. (doi:10.1100/tsw.2010.182)

Trajkovic K, Hsu C, Chiantia S, Rajendran L, Wenzel D, Wieland F, Schwille P, Brugger B \& Simons M 2008 Ceramide triggers budding of exosome vesicles into multivesicular endosomes. Science $\mathbf{3 1 9}$ 1244-1247. (doi:10.1126/science.1153124)

Tremellen K 2008 Oxidative stress and male infertility - a clinical perspective. Human Reproduction Update 14 243-258. (doi:10.1093/ humupd/dmn004) 
Tsai PS, De Vries KJ, De Boer-Brouwer M, Garcia-Gil N, Van Gestel RA, Colenbrander B, Gadella BM \& Van Haeften T 2007 Syntaxin and VAMP association with lipid rafts depends on cholesterol depletion in capacitating sperm cells. Molecular Membrane Biology 24 313-324. (doi:10.1080/09687860701228692)

Tsai PS, Garcia-Gil N, van Haeften T \& Gadella BM 2010 How pig sperm prepares to fertilize: stable acrosome docking to the plasma membrane. PLOS ONE 5 e11204. (doi:10.1371/journal.pone.0011204)

Utleg AG, Yi EC, Xie T, Shannon P, White JT, Goodlett DR, Hood L \& Lin B 2003 Proteomic analysis of human prostasomes. Prostate 56 150-161. (doi:10.1002/pros.10255)

Veveris-Lowe TL, Kruger SJ, Walsh T, Gardiner RA \& Clements JA 2007 Seminal fluid characterization for male fertility and prostate cancer: kallikrein-related serine proteases and whole proteome approaches. Seminars in Thrombosis and Hemostasis 33 87-99. (doi:10.1055/s-2006-958467)

Visconti PE, Westbrook VA, Chertihin O, Demarco I, Sleight S \& Diekman AB 2002 Novel signaling pathways involved in sperm acquisition of fertilizing capacity. Journal of Reproductive Immunology 53 133-150. (doi:10.1016/S0165-0378(01)00103-6)
Wang XF, Zhou CX, Shi QX, Yuan YY, Yu MK, Ajonuma LC, Ho LS, Lo PS, Tsang LL, Liu Y et al. 2003 Involvement of CFTR in uterine bicarbonate secretion and the fertilizing capacity of sperm. Nature Cell Biology $\mathbf{5}$ 902-906. (doi:10.1038/ncb1047)

Wira CR, Fahey JV, Sentman CL, Pioli PA \& Shen L 2005 Innate and adaptive immunity in female genital tract: cellular responses and interactions. Immunological Reviews 206 306-335. (doi:10.1111/j.0105-2896.2005. 00287.x)

Zhao Z, Zeng G, Ma W, Ou L \& Liang Y 2011 Peripheral blood reverse transcription PCR assay for prostate stem cell antigen correlates with androgen-independent progression in advanced prostate cancer. International Journal of Cancer 131 902-910. (doi:10.1002/ijc.26459)

Received 6 August 2013

First decision 9 September 2013

Revised manuscript received 14 October 2013

Accepted 22 October 2013 